\title{
Analisis dan Perancangan Sistem Informasi Akuntansi Pengelolaan Tabungan Siswa pada SD Ar-Raudah Bandarlampung
}

\author{
Damayanti $^{1}$, H Sulistiani ${ }^{2}$, E F G S Umpu ${ }^{3}$ \\ Program Studi Sistem Informasi ${ }^{1}$, Universitas Teknokrat Indonesia \\ Program Studi Sistem Informasi Akuntansi ${ }^{23}$, Universitas Teknokrat Indonesia \\ Jl. Z.A. Pagar Alam No. 9-11, Labuhan Ratu, Bandarlampung, Indonesia ${ }^{123}$ \\ damayanti@teknokrat.ac.id ${ }^{1}$, henisulistiani@teknokrat.ac.id*2, eronifebri.md@gmail.com
}

\author{
diterima: 1 Agustus 2020 \\ direvisi: 18 Januari 2021 \\ dipublikasi: 1 Maret 2021
}

\begin{abstract}
Abstrak
Penerapan teknologi informasi dalam suatu organisasi sangatlah penting untuk mempermudah dan mempercepat pengelolaan aktivitas yang terjadi. Hal ini yang menjadikan dasar dalam pengembangan sistem informasi akuntansi pengelolaan tabungan siswa di SD Ar-Raudah Bandarlampung. Pengelolaan tabungan siswa saat ini masih dilakukan secara manual sehingga sering terjadi kesalahan perhitungan, pengisian data saat pelaporan tabungan dan kurang responsif ketika pencarian data. Selain itu, staff administrasi juga membutuhkan waktu yang lama untuk menghasilkan laporan tabungan per siswa dan laporan tabungan keseluruhan. Tujuan dikembangkannya sistem informasi tabungan siswa ini yaitu memudahkan staff administrasi dalam pembuatan laporan tabungan siswa dan meminimalisir kesalahan pencatatan tabungan siswa.
\end{abstract}

Kata kunci: Sekolah; Sistem Informasi Akuntansi; Tabungan

\begin{abstract}
Application of information technology in an organization is very important to facilitate and accelerate the management of activities that occur. This is the basis for the development of accounting information systems for managing student savings at SD Ar-Raudah Bandarlampung. Management of student savings is still done manually so that calculation errors often occur, filling in data when reporting savings and less responsive when searching for data. In addition, administrative staff also needs a long time to produce savings reports per student and overall savings report. The purpose of developing student savings information system is to facilitate administration staff in making reports and to minimize errors in recording student savings.
\end{abstract}

Keywords: School; Accounting Information System; Saving

\section{Pendahuluan}

Komputer adalah salah satu perangkat yang sangat dibutuhkan saat ini untuk mengolah data dan menghasilkan informasi, dikarenakan komputer dapat bekerja secara mudah, cepat, dan akurat. Diharapkan dengan adanya informasi tersebut mampu membantu organisasi mengatasi permasalahan untuk pengolahan data, yang akhirnya dapat mempermudah dan memperlancar kegiatan pengolahan data dan penyajian informasi bagi organisasi [1][2].

Teknologi informasi dan sistem informasi merupakan pengetahuan dasar yang dikembangkan lebih profesional didalam suatu organisasi. Adanya kegiatan terkomputerisasi yang mengolah data menjadi informasi menjadi sangat penting [3]. Hal tersebut dikarenakan pengolahan data tersebut mampu memberikan manfaat yang besar bagi kinerja organisasi. Salah satu organisasi yang memerlukan sistem terkomputerisasi adalah sekolah. 
Sekolah Dasar Ar-Raudah Bandar Lampung adalah salah satu lembaga pendidikan yang ada di Bandar Lampung. Salah satu permasalahan yang sedang dihadapi oleh SD ArRaudah Bandar Lampung adalah mengenai pengolahan data tabungan siswa yang saat ini sistemnya masih dikerjakan secara manual. Pencatatan dan penyimpanan data tabungan ditulis didalam buku, dan perhitungannya masih dikerjakan dengan alat bantu kalkulator. Akibatnya sering terjadi kesalahan perhitungan, pengisian data saat pelaporan tabungan dan kurang responsif ketika pencarian data.

Agar permasalahan tersebut dapat teratasi, perlu dikembangkan sistem informasi yang mendukung dan membantu para guru ketika Orang Tua murid ingin membayar Tabungan dan menghindar terjadinya kehilangan dan juga memudahkan ketika ingin mencari datadata Tabungan. Seperti sistem yang pernah dikembangkan dalam mengatasi permasalahan tabungan siswa di SMK Nusa Putra Kota Tangerang [4] dan permsalahan tabungan siswa di Baitul Maal Wat Tamwil (BMT) [5]. Dengan adanya sistem tersebut diharapkan mampu memudahkan proses penyimpanan data dan pencarian data [6]. Penggunaan teknologi informasi sudah terbukti sebagai salah satu media informasi yang efektif dan efisien dalam penyebaran informasi [7]. Penggunaan sistem informasi memungkinkan adanya otomatisasi pekerjaan dan fungsi pelayanan untuk mewujudkan pelayanan yang baik [8].

\subsection{Sistem Informasi}

\section{Kajian Pustaka}

Sistem adalah rangkaian dari dua atau lebih komponen-komponen yang saling berhubungan, yang berinteraksi untuk mencapai suatu tujuan [9]. Sebagian besar sistem terdiri dari subsistem yang lebih kecil yang mendukung sistem yang lebih besar. Beberapa komponen dalam sistem informasi adalah sebagai berikut:

1. Komponen input adalah data yang masuk ke dalam system informasi.

2. Komponen model adalah kombinasi prosedur, logika dan model matematika yang memproses data yang tersimpan dibasis data dengan cara yang sudah di tentukan untuk menghasilkan keluaran yang diinginkan.

3. Komponen output adalah hasil informasi yang berkualitas dan dokumentasi yang berguna untuk semua tingkatan manajemen serta semua pemakai sistem.

4. Komponen teknologi adalah alat dalam sistem informasi, teknologi digunakan dalam menerima input, menjalankan model, menyimpan dan mengakses data, menghasilkan dan mengirimkan output dan memantau pengendalian sistem.

5. Komponen basis data adalah kumpulan data yang saling berhubungan yang tersimpan didalam komputer dengan menggunakan software database.

6. Komponen control adalah komponen yang mengendalikan gangguan terhadap sistem informasi.

\subsection{Sistem Informasi Akuntansi}

Sistem Informasi Akuntansi adalah suatu sistem yang mengumpulkan, mencatat, menyimpan, dan memproses akuntansi dan data lain untuk menghasilkan informasi bagi pembuat keputusan [9]. Fungsi dari sistem informasi akuntansi adalah sebagai berikut:

1. Mengumpulkan serta menyimpan data aktivitas atau transaksi keuangan perusahaan.

2. Memproses data keuangan menjadi informasi dalam pengambilan keputusan manajemen tentang perencanaan dan pengendalian usaha.

3. Melakukan kontrol yang efektif dan tepat terhadap aset-aset perusahaan

4. Pengawasan terhadap semua aktivitas keuangan perusahaan.

5. Efisiensi biaya dan waktu terhadap kinerja keuangan. 
6. Penyajian data keuangan yang sistematis dan akurat dalam periode akuntansi yang tepat.

\section{Metode Penelitian}

Pengembangan sistem tabungan siswa di SD ArRaudah Bandarlampung menggunakan metode Extreme Programming (XP). Tahapan pengembangan perangkat lunak XP terdiri dari planning, design, coding dan testing [10]. Tahapan awal yang dilakukan adalah planning, pada tahapan ini penulis melakukan pengumpulan data melalui proses wawancara, observasi dan studi literatur. Selain itu penulis juga melakukan analisis terhadap jalannya sistem tabungan siswa SD ArRaudah Bandarlampung saat ini dan melakukan analisis kebutuhan sistem yang akan dikembangkan. Tahapan kedua, penulis mulai melakukan perancangan sistem yang akan dikembangkan agar hasil sistem sesuai dengan kebutuhan pengguna. Tahapan ketiga, penulis melakukan pengkodingan dengan menggunakan bahasa pemrograman Java (Netbeans) dan Xampp. Tahapan terkahir, penulis melakukan pengujian sistem dengan mengaplikasikan sistem yang dikembangkan ke staff administrasi SD ArRaudah Bandarlampung. Jika sistem yang dikembangkan masih belum sesuai dengan kebutuhan pengguna, maka sistem akan diperbaiki sehingga dapat memenuhi kebutuhan pengguna. Gambar 1 menunjukkan tahapan penelitian yang dilakukan oleh penulis.

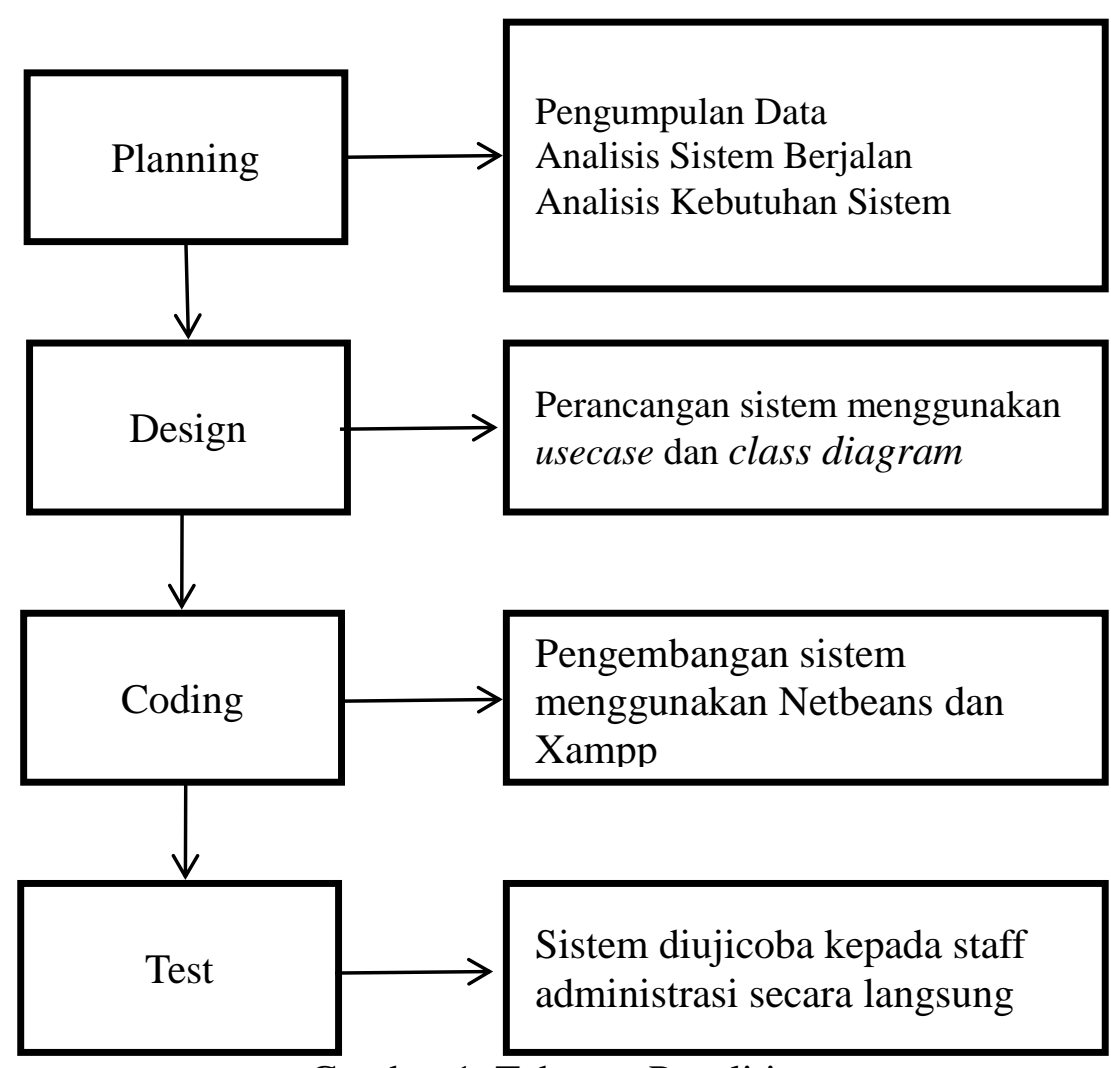

Gambar 1. Tahapan Penelitian

\subsection{Pengumpulan Data}

Metode pengumpulan data yang digunakan dalam penelitian ini adalah sebagai berikut:

1. Wawancara (Interview), metode ini dilakukan dengan cara tanya jawab secara langsung kepada Kepala sekolah dan Bendahara sekolah mengenai permasalahan sistem tabungan siswa. 
2. Pengamatan (Observation), metode ini dilakukan dengan mengamati secara langsung mengenai sistem yang sedang berjalan di sekolah yang bertujuan untuk mendapatkan data-data yang benar dan akurat.

3. Tinjauan Pustaka (Literature Review), metode yang dilakukan dengan mengutip beberapa sumber pustaka yang digunakan sebagai referensi yang ada hubungannya dengan data yang diperlukan.

\subsection{Analisis Sistem Berjalan}

Sistem pelaksanaan dan pengarsipan data Tabungan sekolah di SD Ar-Raudah yaitu :

1. Pengolahan data masih dilakukan manual. Data siswa berupa informasi nomor induk siswa, nama, kelas, alamat, nama wali, no hp, alamat wali, dan data transaksi Tabungan.

2. Masih mengalami kesulitan untuk mengetahui siswa yang sudah melakukan Penabungan sebelumnya ketika ingin menabung kembali.

3. Data disimpan dalam bentuk dokumen kertas yang dapat memakan banyak tempat, dan sulit dalam pencarian data.

\subsection{Analisis Kebutuhan Sistem}

Analisa kebutuhan sistem dilakukan untuk mengetahui keperluan yang dibutuhkan untuk menerapkan sistem. Kebutuhan sistem yang diperlukan ini terdiri dari kebutuhan fungsional dan non fungsional yang akan dibutuhkan.

1. Kebutuhan Fungsional

Persyaratan kebutuhan fungsional adalah pernyataan layanan yang harus disediakan oleh sistem, bagaimana sistem harus bereaksi terhadap masukan tertentu, dan bagaimana sistem harus berperilaku dalam situasi tertentu. Kebutuhan fungsional terdiri dari :

a) Admin

1. Dapat melakukan Login

2. Dapat mengelola data siswa

3. Dapat mengelola data Tabungan

4. Dapat keluar sistem dengan melakukan Logout

b) Kepala Sekolah

1. Dapat melakukan login sistem

2. Dapat mengelola data admin

3. Dapat melihat laporan Tabungan

4. Dapat keluar sistem dengan melakukan Logout

2. Kebutuhan Non Fungsional

Analisa kebutuhan non fungsional terdiri dari kebutuhan perangkat keras komputer (hardware) dan perangkat lunak (software). Kebutuhan non fungsional sebagai alat bantu pendukung. Berikut uraian spesifikasi dari perangkat yang digunakan:

a) Perangkat Keras Komputer (Hardware)

Spesifikasi perangkat keras (hardware) yang digunakan adalah :

1. LCD monitor 14inch

2. Prosesor Intel Core i3

3. Memory (RAM) $4 \mathrm{~Gb}$

b) Perangkat Lunak Komputer (Software)

Spesifikasi perangkat lunak (software) yang digunakan adalah :

1. Sistem Operasi Windows 10 
2. Microsoft Office 13

3. Visio

4. Netbeans

5. MySqL

6. Hardisk $350 \mathrm{~Gb}$, RAM $2 \mathrm{~Gb}$

7. Load Time: 15.042 detik

\subsection{Usecase Diagram}

\section{Hasil dan Pembahasan}

Usecase Diagram dirancangan untuk mendeskripsikan sebuah interaksi antara satu atau lebih aktor dengan sistem informasi yang akan dibuat. Usecase digunakan untuk mengetahui fungsi apa saja yang ada di dalam sebuah sistem informasi dan siapa saja yang berhak menggunakan fungsi-fungsi itu. Rancangan usecase diagram dapat dilihat pada Gambar 2.

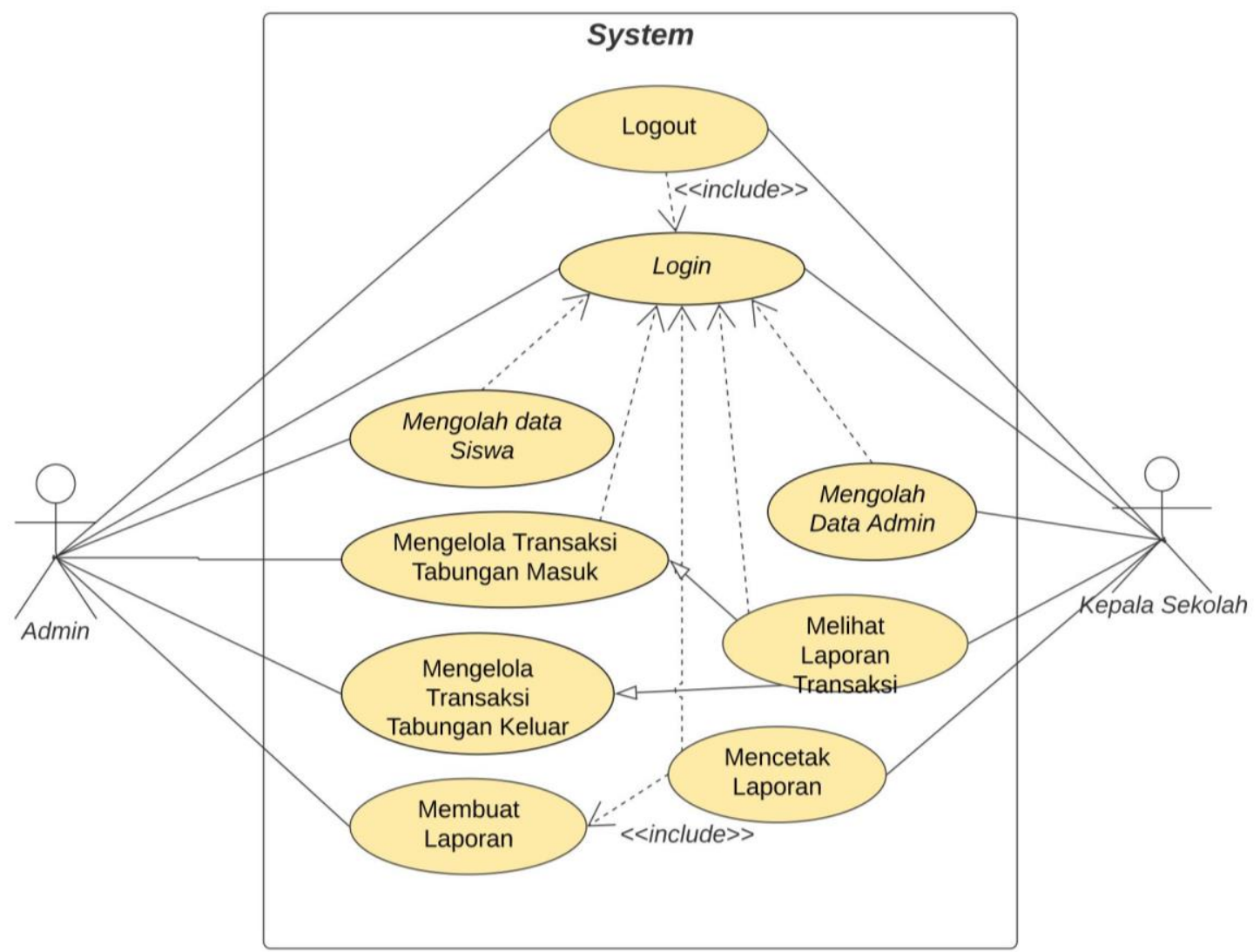

Gambar 2. Usecase Diagram Sistem Tabungan Siswa

Berdasarkan gambar 2 dapat diketahui bahwa yang akan menggunakan sistem hanya admin dan kepala sekolah. Admin yang merupakan staff administrasi sekolah dapat melakukan kegiatan sebagai berikut:

a. Admin dapat melakukan login untuk dapat mengakses sistem

b. Admin dapat mengelola data siswa, admin menambah, mengubah, menghapus, mencari dan melihat data siswa.

c. Admin dapat mengelola data Transaksi Tabungan , admin menambah, menghapus, mencari dan melihat data Tabungan.

d. Admin dapat mencetak laporan Transaksi masuk, keluar, dan keseluruhan. 
e. Admin dapat keluar dari sistem dengan melakukan logout.

Sedangkan kepala sekolah dalam sistem tabungan yang dikembangkan ini dapat melakukan kegiatan-kegiatan sebagai berikut:

a. Kepala sekolah dapat mengakses sistem dengan melakukan login

b. Kepala sekolah dapat melihat dan mencetak laporan Transaksi Tabungan

c. Kepala sekolah dapat mengelolah data admin, Kepala Sekolah menambah, mengubah, menghapus, mencari dan melihat data admin.

d. Kepala sekolah dapat keluar dari sistem dengan melakukan logout.

\subsection{Class Diagram}

Class diagram menggambarkan interaksi antar objek dan mengindikasikan komunikasi diantara objek-objek tersebut. class diagram dari sistem yang akan dikembangkan dapat dilihat pada gambar 3. Class diagram di bawah memiliki 5 class yaitu class data siswa, data admin, tabungan masuk, tabungan keluar, dan cetak laporan yang mana semua terkoneksi ke database.

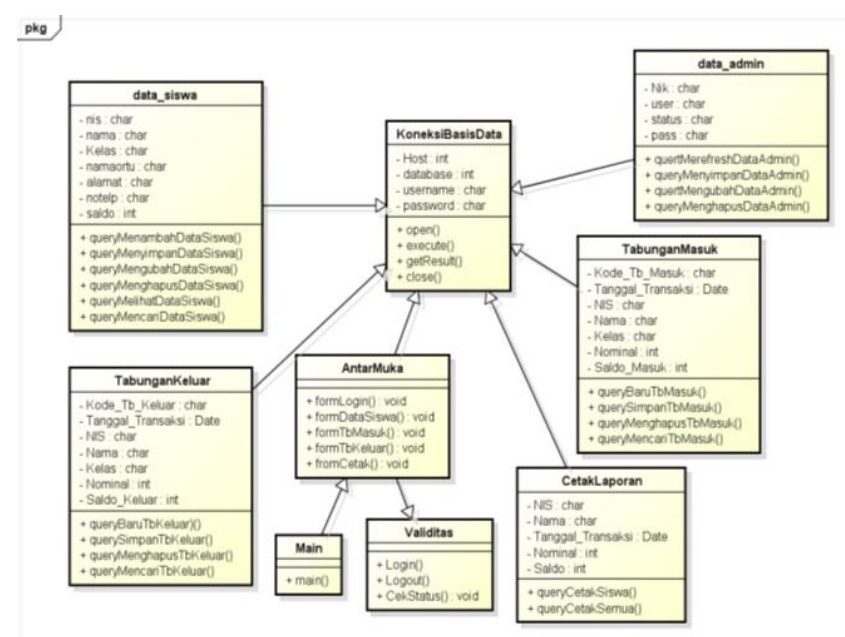

Gambar 3. Class Diagram Sistem Tabungan Siswa

\subsection{Implementasi Sistem}

Implementasi sistem informasi Tabungan Siswa dilakukan berdasarkan perancangan usecase dan class diagram sistem dan rancangan tampilan sistem. Implementasi perancangan tersebut kedalam kode program dengan menggunakan software pemrograman Java sehingga menghasilkan sistem informasi Tabungan Siswa berbasis desktop. Hasil implementasi sistem ditunjukkan pada penjelasan dibawah ini.

1. Halaman Login

Halaman login merupakan halaman yang digunakan untuk dapat mengakses sistem.

Pada halaman login harus memasukkan username, password dan memilih status.

Tampilan halaman login dapat dilihat pada Gambar 4. 


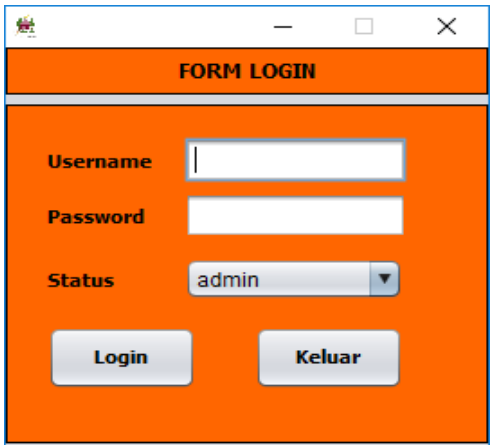

Gambar 4. Halaman Login

\section{Halaman Utama}

Halaman utama merupakan tampilan utama pada sistem setelah melakukan login sistem. Pada halaman utama terdiri dari beberapa menu yang dapat diakses dalam sistem, yang terdiri dari menu data siswa, Data Tabungan Masuk, Data Tabungan Keluar, Cetak Laporan dan Informasi Saldo. Tampilan halaman utama dapat dilihat pada Gambar 5.

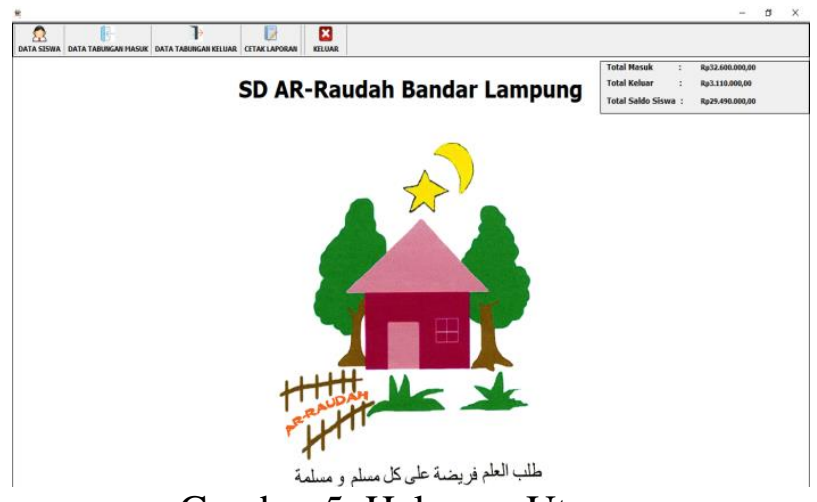

Gambar 5. Halaman Utama

3. Halaman Data Siswa

Halaman data siswa merupakan halaman yang dapat digunakan untuk mengelola data siswa, pada halaman ini terdiri dari berberapa field yaitu Nis, nama, kelas, nama orang tua, alamat, no telepon, dan saldo. Pada halaman data siswa ini juga admin dapat menambah, mengubah, menyimpan,, menghapus dan mencari data siswa. Tampilan halaman data siswa dapat dilihat pada Gambar 6.

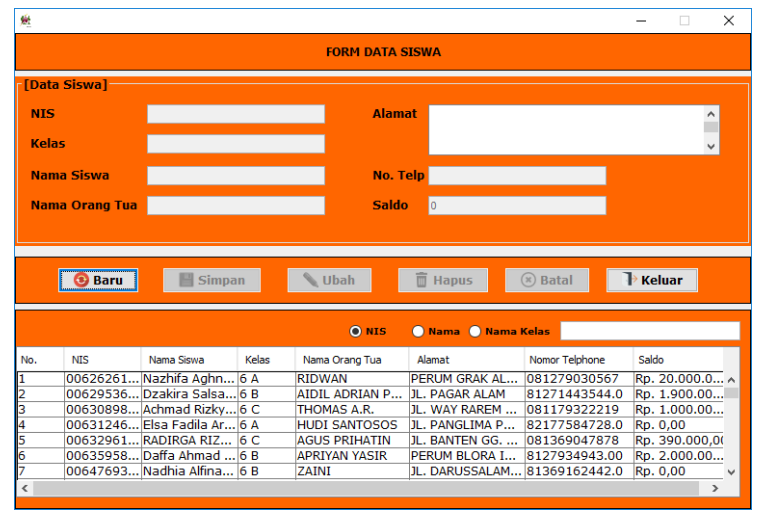

Gambar 6. Halaman Data Siswa

4. Halaman Tabungan Masuk 
Halaman data Tabungan Masuk merupakan halaman yang dapat digunakan untuk mengelola Tabungan Masuk, pada halaman ini terdiri dari berberapa field yaitu tanggal transaksi, kode transaksi, nis, nama, kelas, nominal, dan saldo tabungan. Pada halaman Tabungan Masuk ini juga admin dapat menambah, menyimpan, menghapus dan mencari Tabungan Masuk. Tampilan halaman Tabungan Masuk dapat dilihat pada Gambar 7.

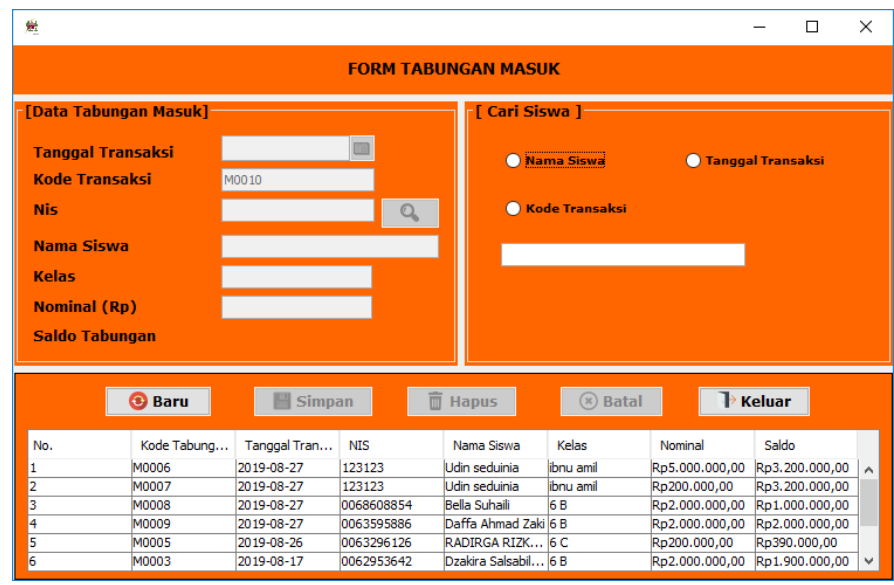

Gambar 7. Halaman Tabungan Masuk

5. Halaman Tabungan Keluar

Halaman data Tabungan Keluar merupakan halaman yang dapat digunakan untuk mengelola Tabungan Keluar, pada halaman ini terdiri dari berberapa field yaitu tanggal transaksi, kode transaksi, nis, nama, kelas, nominal, dan saldo tabungan. Pada halaman Tabungan Keluar ini juga admin dapat mengurangi, menyimpan, menghapus dan mencari Tabungan Keluar. Tampilan halaman Tabungan Keluar dapat dilihat pada Gambar 8.

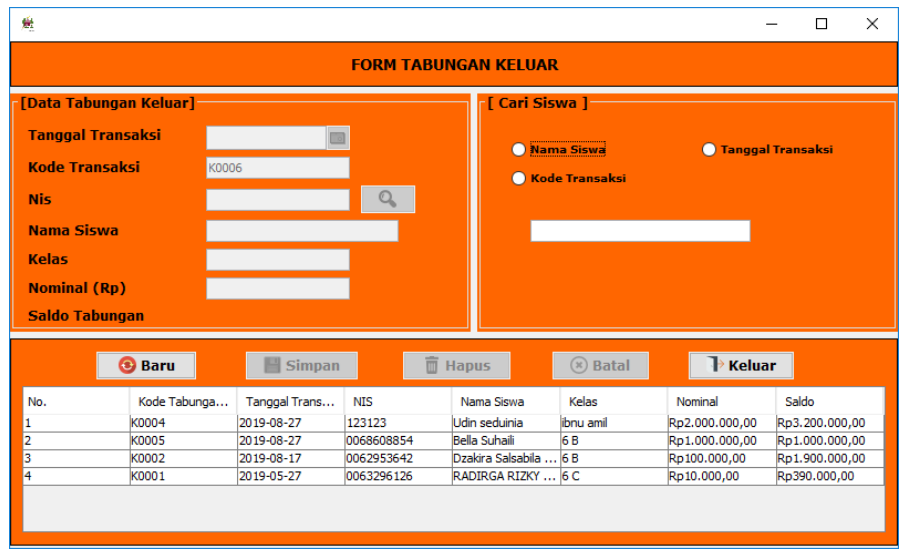

Gambar 8. Halaman Tabungan Keluar

\section{Halaman Cetak Laporan}

Halaman cetak laporan adalah merupakan form untuk melihat data tabungan masuk dan keluar juga dapat melihat total masuk, total keluar, dan total keseluruhan. Halaman cetak laporan ini memiliki dua pilihan dimana admin dapat memilih cetak siswa dan cetak semua. Halaman cetak laporan dapat dilihat pada Gambar 9. 
Volume 11 Nomor 1 Edisi Maret 2021

P-ISSN 2088-2270, E-ISSN 2655-6839

DOI 10.34010/jati.v11i1

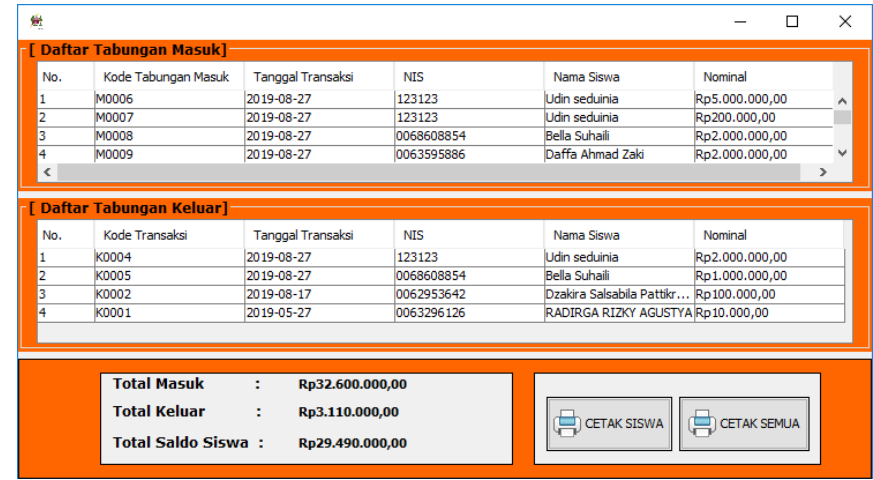

Gambar 9. Halaman Cetak Laporan

Setelah memilih cetak siswa admin dapat mencetak laporan persiswa sesuai dengan nama yang dipilih halaman cetak siswa dapat dilihat pada gambar 10 .

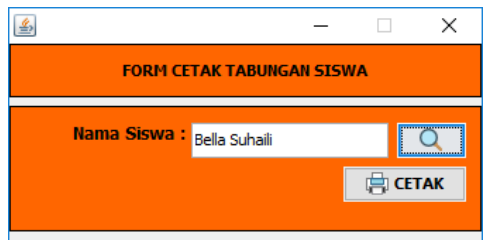

Gambar 10. Halaman Cetak Laporan Per Siswa

Lalu akan tampil cetak laporan yang berisikan judul, nama siswa nis, nominal masuk, dan nominal keluar, serta tanda tangan bendahara dapat dilihat pada gambar 11 .

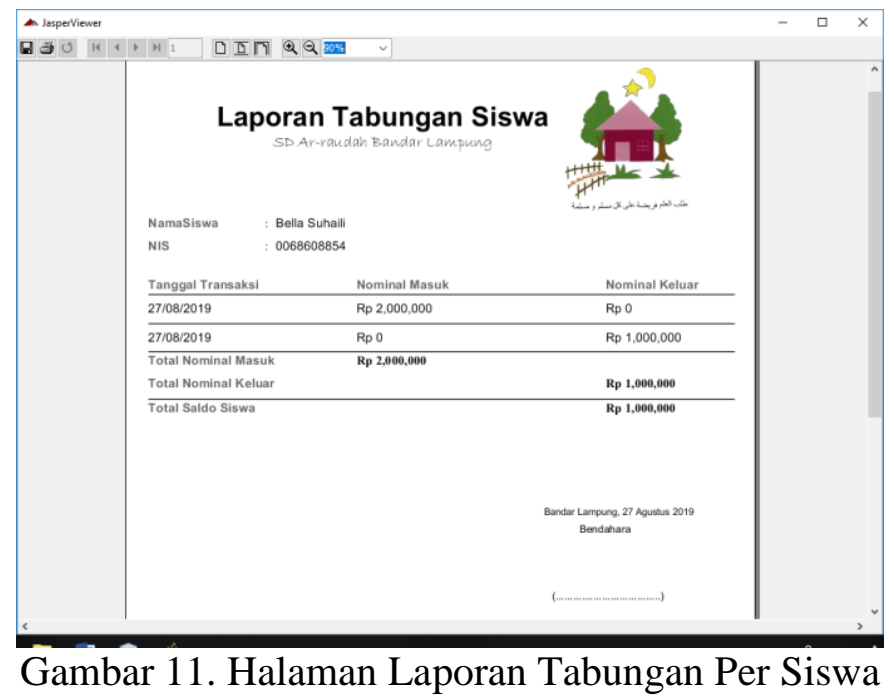

Jika pengguna memilih form cetak semua, admin memilih sesuai tanggal priode yang ingin dicetak. Halaman cetak laporan berdasarkan periode dapat dilihat pada gambar 12.

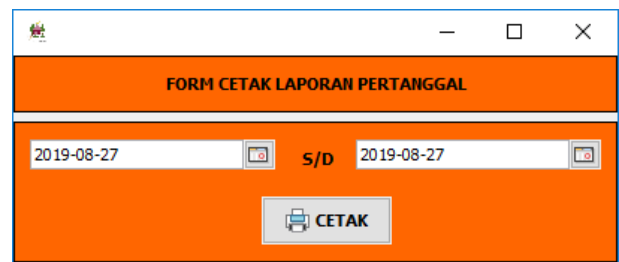

Gambar 12. Halaman Cetak Laporan Berdasarkan Periode 
Lalu akan tampil cetak semua yang berisikan judul, nama seluruh siswa, tanggal transaksi nominal masuk dan keluar serta tanda tangan, bentuk laporan berdasarkan periode dapat dilihat pada gambar 13.

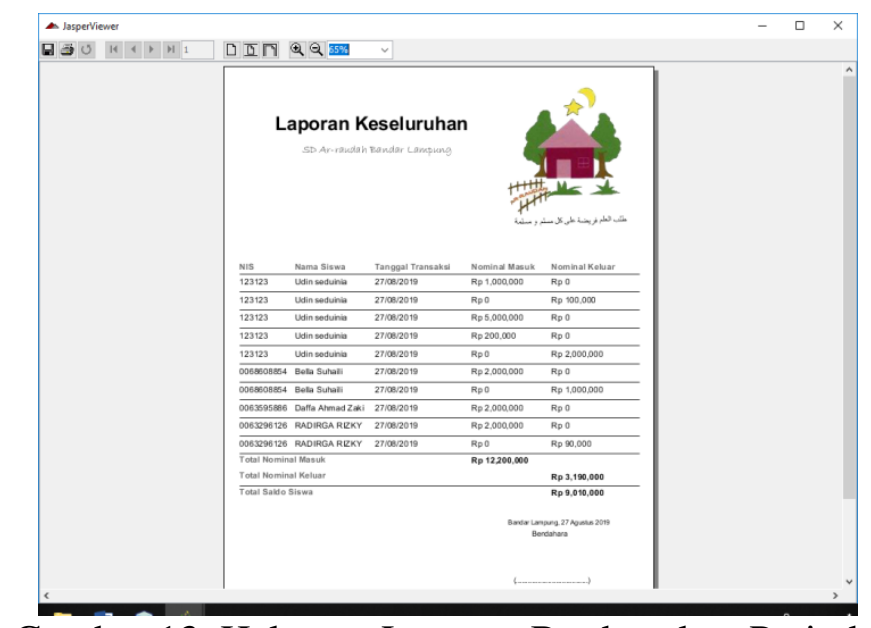

Gambar 13. Halaman Laporan Berdasarkan Periode

\section{Kesimpulan}

Berdasarkan hasil implementasi sistem informasi yang telah dibuat, maka dapat disimpulkan bahwa sistem Tabungan Siswa dibangun menggunakan bahasa pemograman Java dan database Mysql. Serta perancangan sistem dengan menggunakan usecase dan class diagram. Sistem yang dikembangkan mampu membantu staff administrasi untuk mengelola data tabungan siswa dan dapat mempermudah dalam beberapa proses pengelolaan tabungan siswa di SD Ar-Raudah Bandarlampung. Hal ini dikarenakan data dapat disimpan dalam sistem sehingga memudahkan dalam pencarian data serta mempermudah pembuatan laporan tabungan siswa.

\section{Ucapan Terima Kasih}

Penulis mengucapkan terima kasih kepada Direktorat Riset dan Pengabdian Masyarakat, Kemenristek/BRIN RI yang telah memberi dukungan terhadap seluruh kegiatan Program Kemitraan Masyarakat Stimulus (PKMS) yang dilaksanakan pada tahun 2020.

\section{Daftar Pustaka}

[1] Dian Permana Putra dan Dedi Irawan, "Pembuatan Aplikasi Tabungan dan Tarik Tunai pada Koperasi BMT El Ihsan," Prosiding KMSI (Konferensi Mahasiswa Sistem Informasi), 2018.2 Tersedia: http://ojs.stmikpringsewu.ac.id/index.php/procidingkmsi/article/viewFile/617/550. [Diakses: 2 Juli 2020]

[2] Suciyati Wulandari, "Rancang Bangun Sistem Informasi Budgeting Ormawa (Organisasi Mahasiswa) Universitas Muhammadiyah Semarang Berbasis Web," Media Elektrika, Vol.13, No.1, Juni 2020. Tersedia: https://jurnal.unimus.ac.id/index.php/ME/article/view/5965. [Diakses: 26 Juli 2020].

[3] Tiolina Evi dan Malabay, "Analisis Pengembangan Aplikasi Web untuk Profil Perusahaan," Seminar Nasional Informatika (Semnasif), Vol. 1, No. 5 (2009). Tersedia: http://jurnal.upnyk.ac.id/index.php/semnasif/article/view/915. [Diakses: 2 Juni 2020]. 
[4] Suwarto, Nasril Sany dan Eka Indriani, "Sistem Informasi Tabungan Siswa Berbasis Web Pada Sekolah Menengah Kejuruan (SMK) Nusa Putra Kota Tangerang," Journal Sensi: Strategic of Education in Information System, Vol. 4 No. 2 (2018). Tersedia: http://ejournal.raharja.ac.id/index.php/sensi/article/view/650/576. [Diakses: 6 Juni 2020].

[5] Rifa Nurafifah Syabaniah, Andi Riyanto, Selviana dan Eva Marsusanti, "Pemanfaatan Aplikasi Tabungan Siswa Berbasis Web Pada Pendidikan Anak Usia Dini (PAUD)," Syntax: Jurnal Informatika Vol. 8, No. 2, 2019. Tersedia: https://journal.unsika.ac.id/index.php/syntax/article/view/2162. [Diakses: 26 Juli 2020].

[6] Eka Lisna Ramadhani, Heni Sulistiani dan Fikri Hamidy, "Rancang Bangun Sistem Informasi Akuntansi Jasa Cuci Mobil (Studi Kasus: Cucian Gading Putih)," Jurnal Teknologi dan Sistem Informasi (JTSI), Vol. 1, No. 1, Juni 2020, 22-30. Tersedia: http://jim.teknokrat.ac.id/index.php/sisteminformasi/article/view/53. [Diakses: 26 Juli 2020].

[7] Ayu Vidiasari dan Dedi Darwis, "Perancangan Sistem Informasi Akuntansi Penjualan Kredit Buku Cetak (Studi Kasus: CV Asri Mandiri)," Jurnal Madani: Ilmu Pengetahuan, Teknologi, dan Humaniora, Vol. 3, No. 1, Maret 2020: 13 - 24. Tersedia: http://jurnalmadani.org/index.php/madani/article/view/77/64. [Diakses: 26 Juli 2020].

[8] Damayanti dan Nina Nirmalasari, "Sistem Informasi Manajemen Penggajian Dan Penilaian Kinerja Pegawai Pada SMK Taman Siswa Lampung," Jurnal Teknologi Informasi dan Ilmu Komputer (JTIIK), Vol.6, No. 4, Juni 2019. Tersedia: http://jtiik.ub.ac.id/index.php/jtiik/article/view/1003. [Diakses: 6 Juni 2020].

[9] Romney, M. B. and Steinbarth, P. J. 2015. Accounting Information Systems. 13th edn. England: Pearson Educatial Limited.

[10] Suryantara, I. G. N. 2017. Merancang Aplikasi Dengan Metodologi Extreme Programmings. Jakarta: Elexmedia. 